\title{
Investigation of Cold Work Hardening Behavior of AISI 304 Stainless Steel
}

\author{
Uğur Özdemir, Selçuk Keskinkılıç, Filiz Kumdalı Acar, Mustafa Acarer
}

\begin{abstract}
In this present study, the cold work hardening behavior of AISI 304 austenitic stainless steel has been investigated as a function of stress rate. For this purpose, tensile specimens were cut from coiled 304 stainless steel stripe with $12 \mathrm{~mm}$ width and 0.8 $\mathrm{mm}$ thickness. Different stress loads performed on each specimen at room temperature. Microstructures of the specimens were characterized by optical microscope and hardness values were compared. Experimental results showed that, hardness of AISI 304 stainless steel is increased by cold deformation drastically. Because of long homogenous plastic deformation area and very short necking period, grain orientation was only visible close the tensile load. This behavior is evaluated usefully in both production and serving conditions.
\end{abstract}

Keywords - 304Stainless Steel, cold work hardening, microstructure

\section{INTRODUCTION}

B ECAUSE of its technological importance, 304 stainless steel (SS) has been the focus of a number of experimental studies [1-7]. 304 stainless steel was one of the $\mathrm{Cr}-\mathrm{Ni}$ austenitic stain-less steel in 300 series stainless steel which is extensively used as it possess various applications such as house wear, chemical industry, building material, and food industry because of the excellent corrosion resistance, heat resistance and mechanical properties.[2-3] Austenitic stainless steels, characterized by a high work hardening rate and low thermal conductivity.[4] Austenitic stainless steel is thermodynamically stable over a wide range of temperatures and it can be hardened only by cold working. As the percentage cold work increases, there is a diminishing increase (increase with lower rate) on strength.

Generally it is seen that increase in strength with increase in cold work results in lowering of $\%$ elongation. This is due to the fact that at higher amount of reductions, there are fewer free dislocations to become entangled. [5] Present study investigates the hardening trend of AISI 304 austenitic

U. Özdemir is with the Gedik Welding Inc. 34906 Istanbul, Turkey, (e-mail: uozdemir@gedik.com.tr)

S. Keskinkılıç is with Gedik Welding Inc. 34906 Istanbul, Turkey, (e-mail: skeskinkilic@gedik.com.tr).

F. K. Acar is with Gedik Welding Inc. 34906 Istanbul, Turkey, (e-mail: facarf@gedik.com.tr)

M. Acarer is with the Metallurgical and Materials Engineering, Department, Selçuk University, 42250 Konya, Turkey, (e-mail: m_acarer@yahoo.com). stainless steel with rising stress.

\section{EXPERIMENTAL STUDIES}

Tensile specimens were prepared from the AISI 304 stainless steel $12 \mathrm{~mm}$ width $0.8 \mathrm{~mm}$ thick stripe. The chemical composition of the AISI 304 stainless steel used was given in Table 1. Tensile tests were carried out at room temperature using Zwick/Roell at a constant cross-head speed of 1 mm.min-1 which corresponds to strain rate of $6.67 \times 10^{-4} \mathrm{~s}^{-1}$. One specimen was pulled off until its rupture point which is $600 \mathrm{MPa}(\mathrm{A})$. The load was cut off at $550 \mathrm{MPa}(\mathrm{B}), 450 \mathrm{MPa}$ (C), 300MPa (D), 200MPa (E) on other specimens. No load was applied on one specimen (F). Tensile specimens were cut from fracture point, necking and possible necking areas then hot mounted for mechanical grinding, polishing up to $1 \mu \mathrm{m}$ diamond suspension and etched by Oxalic Acid $\left(\mathrm{C}_{2} \mathrm{H}_{2} \mathrm{O}_{4}\right)$ solution. Microstructure observations were studied by using an optical microscope. Hardness tests were conducted in BMS Microbul micro Vickers hardness tester with Vickers $5 \mathrm{kgf}$ hardness method.

TABLE I

Chemical Compositions Of The 304 Stainless Steel StriPe Used In The EXPERIMENTS.

\begin{tabular}{|c|c|c|c|c|}
\hline $\mathbf{C}$ & $\mathbf{M n}$ & $\mathbf{S i}$ & $\mathbf{P}$ & $\mathbf{N}$ \\
\hline 0.027 & 1.394 & 0.386 & 0.032 & 0.04 \\
\hline $\mathbf{S}$ & $\mathbf{C r}$ & $\mathbf{N i}$ & $\mathbf{M o}$ & $\mathbf{F e}$ \\
\hline 0.004 & 18.044 & 8.091 & 0.192 & 71.285 \\
\hline
\end{tabular}

\section{RESULTS AND DISCUSSION}

As received AISI 304 Stainless steel has entirely austenitic microstructure (Fig. 2.a). Fig. 2.b, Fig. 2.c, Fig. 2.d, Fig 2.e and Fig. 2.f illustrates the optical micrographs of the specimens pulled until $200 \mathrm{MPa}, 300 \mathrm{MPa}, 450 \mathrm{MPa}, 550 \mathrm{MPa}$ and 600MPa. There is no phase transformation or chromium precipitation was observed since no heat treatment was performed. With the increasing stress, grain orientation and microvoids due to tensile axis were showed up [6]. 

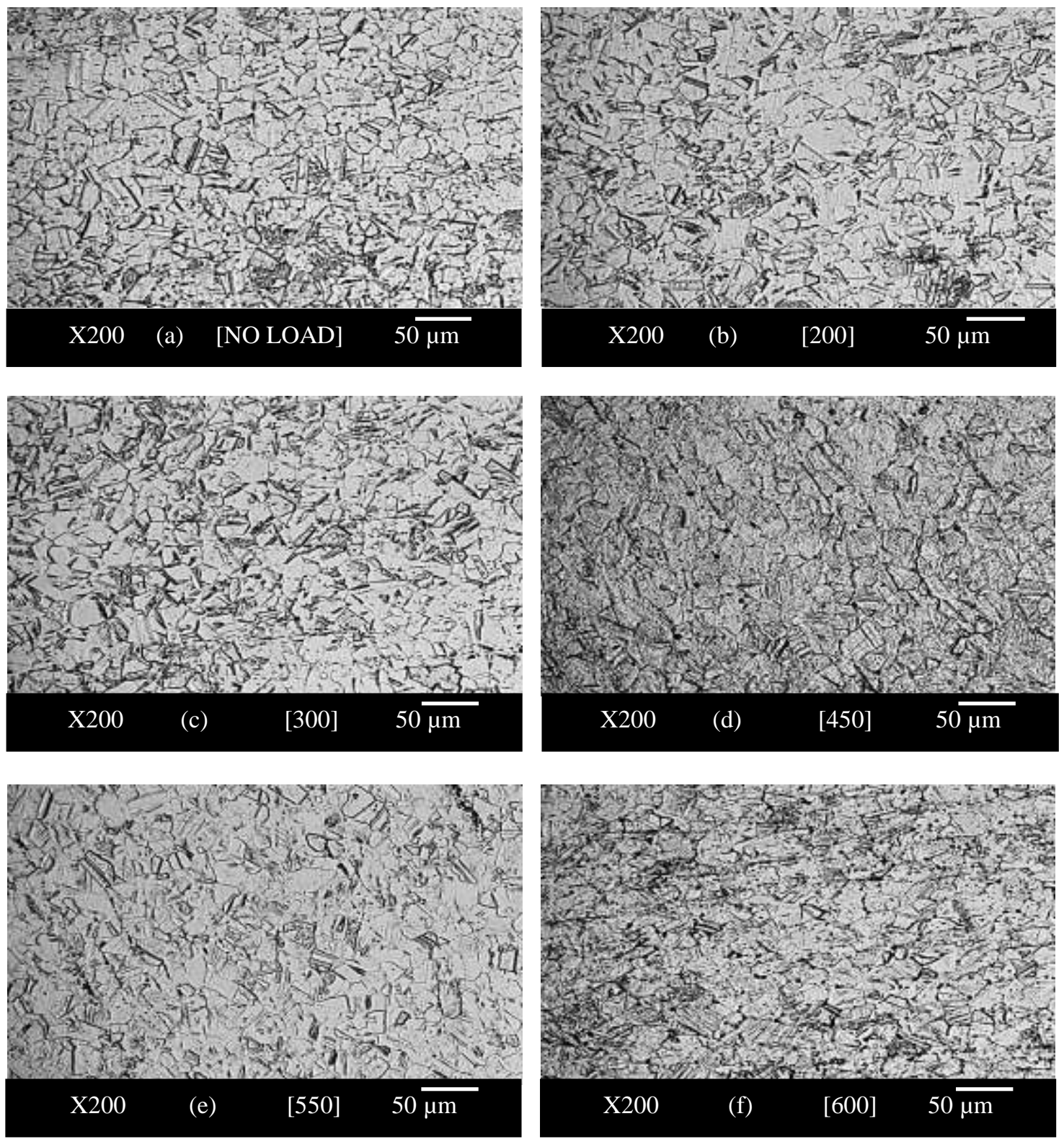

Fig 2. Optical micrographs of AISI 304 Stainless Steel; a) No Load Applied, b) 200MPa, c) 300MPa, d) 450MPa, e)550MPa, f)600MP

\section{A. Microhardness}

Microhardness test results are shown in Table 2. Obviously when compared with the specimens with no load and below yield stress applied, stress applied specimen's hardness values were enhanced by higher stress values. Because of the elastic deformation area, the mechanical properties of the specimens pulled until 300MPa remained as they were

TABLE II.

Microhardness VALUes OF THE SPECIMENS

\begin{tabular}{|c|c|c|c|c|c|c|}
\hline \multicolumn{7}{|c|}{ Hardness Values (HV5) } \\
\hline $\begin{array}{c}\text { Specimen } \\
\text { Name }\end{array}$ & $\mathrm{A}$ & $\mathrm{B}$ & $\mathrm{C}$ & $\mathrm{D}$ & $\mathrm{E}$ & $\mathrm{F}$ \\
\hline $\begin{array}{c}\text { Stress } \\
\text { (Mpa) }\end{array}$ & $\mathbf{6 0 0}$ & $\mathbf{5 5 0}$ & $\mathbf{4 5 0}$ & $\mathbf{3 0 0}$ & $\mathbf{2 0 0}$ & $\begin{array}{c}\text { No } \\
\text { Load }\end{array}$ \\
\hline 1. Analyze & 342,05 & 278,24 & 251,39 & 212 & 175,49 & 176,41 \\
\hline
\end{tabular}

\begin{tabular}{|l|c|c|c|c|c|c|} 
2. Analyze & 331,91 & 273,13 & 256,71 & 211,95 & 176,31 & 175,95 \\
\hline 3. Analyze & 338,75 & 274,92 & 258,5 & 209,14 & 175,94 & 176,25 \\
\hline 4. Analyze & 340,24 & 279,16 & 258,88 & 212,56 & 177,81 & 177,18 \\
\hline 5. Analyze & 344,56 & 284,13 & 253,5 & 208,55 & 177,18 & 176,51 \\
\hline Average & $\mathbf{3 3 9 , 5}$ & $\mathbf{2 7 7 , 8 9}$ & $\mathbf{2 5 5 , 7 9}$ & $\mathbf{2 1 0 , 8}$ & $\mathbf{1 7 6 , 5 4}$ & $\mathbf{1 7 6 , 4 6}$ \\
\hline
\end{tabular}




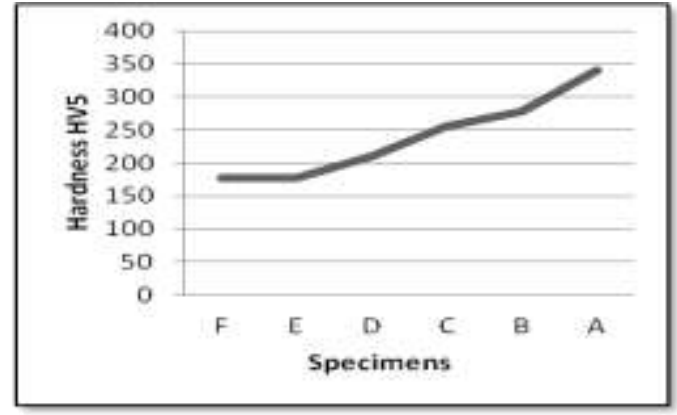

Fig 1. Effect of applied stress on hardness

\section{CONCLUSION}

The effect of cold work on hardness of AISI 304 austenitic stainless steel has been investigated in the present study. Following conclusions could be drawn from this study;

1. Hardness of AISI 304 stainless steel is increased by cold deformation drastically.

2. Microvoids on the grain boundaries were clearly seen with the increasing stress applied.

3. Since it is a widely used austenitic stainless steel type, to avoid unwanted hardening and abrupt rupture or any other failures, process annealing or post heat treatment may be required for cold production line of AISI 304 stainless steel such as wire drawing or cold rolling.

4. For further investigation, optimum heat treatment type and parameters will be studied for specific production types.

\section{REFERENCES}

[1] R. Zauter, F. Petry, H.-J Christ, and H. Maghrabi, "High Temperature Creep Behavior and Microstructure Development of AISI 304 Stainless Steel”, Mater. Sci. Eng., A124, (1990) pp. $125-$ 132.

[2] Y. Peng, J. Gong, Y. Jiang, M. Fu, and D. Rong, Surf. Coat. Technol.304, 16, 2016

[3] Ó. Martín, V. Ahedo, J. Ignacio Santos, P. De Tiedra, and JoséManuel Galán, Mater. Sci. Eng. A 676, 173, 2016

[4] Korkut I., Kasap M., Ciftci I., Seker U., Determination of Optimum Cutting Parameters During Machining of AISI 304 Materials and Design 25(4):303-305, 2004

[5] Gupta R. K., Mathew C., Ramkumar P. Strain Hardening in Aerospace Alloys, Frontiers in Aerospace Engineering, Vol. 4 No. 1 May 2015

[6] Bhadeshia, H.K.D.H.,\&Honeycombe, R. Steels: Microstructure and Properties: Microstructure and Properties. Butterworth-Heinemann, 2011.

[7] J.W.L. Pang, T.M Holden,. J.S. Wright, and T.E. Mason, "The Generation of Intergranular Strains in $309 \mathrm{H}$ Stainless Steel under Uniaxial Loading" Acta mater, (2000), 48, pp. 1131- 1140.

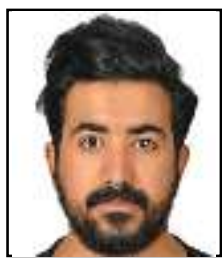

Ugur OZDEMIR, 1993 Ankara/Turkey, has graduated from BSc Metallurgy and Materials Engineering from Gazi University Ankara, Turkey in 2015 and he is currently pursuing his MSc. Degree in the same field in Kocaeli University Kocaeli, Turkey.

He started working as a Research Engineer in
Centre Catala del Plastic, Barcelona where he leaned on a project about nano $\mathrm{CaCO}_{3}$ additive on PP membranes right after his graduation. With completing the project over there, he returned back to Turkey and started working in the biggest welding company of Turkey, Gedik Welding Inc., Istanbul, as R\&D Engineer. He is been leading, assisting, associating to many national and international projects. 